\title{
Analisis Potensi Cadangan dan Kualitas Airtanah di Desa Dukuhwaluh, Kecamatan Kembaran, Kabupaten Banyumas
}

\author{
Analysis of Potential Reserves and Quality of Groundwater in Dukuhwaluh \\ Village, Kembaran District, Banyumas Regency \\ Suwarsito $^{1 *}$, Esti Sarjanti ${ }^{2}$ \\ ${ }^{1,2}$ Pendidikan Geografi, FKIP, Universitas Muhammadiyah Purwokerto \\ *corr-author: suwarsito.ito@ump.ac.id
}

\begin{abstract}
ABSTRAK
Desa Dukuhwaluh selama dekade terakhir ini mengalami perkembangan yang pesat. Perkembangan wilayah menyebabkan terjadinya perubahan penggunaan lahan dari lahan non-terbangun menjadi lahan terbangun. Penelitian ini bertujuan untuk menganalisis pengaruh perubahan penggunaan lahan terhadap potensi cadangan dan kualitas airtanah di Desa Dukuhwaluh, Kecamatan Kembaran, Kabupaten Banyumas. Penelitian ini menggunakan metode survei. Teknik pengambilan sampel menggunakan purposive area sampling. Sampel penelitian sebanyak 4 titik sampel, terdiri dari 2 titik sampel di wilayah Dusun Dampit dan 2 titik sampel di Dusun Dukuhwaluh. Data penelitian meliputi data penggunaan lahan, potensi cadangan airtanah, dan parameter kualitas airtanah. Data penggunaan lahan diperoleh dari data Monografi Desa Dukuhwaluh tahun 2010-2020. Pengumpulan data potensi airtanah dilakukan menggunakan geolistrik, sedangkan data kualitas airtanah diukur langsung di lapangan dan uji laboratorium. Parameter kualitas air yang diukur meliputi kandungan bakteri Escherichia colli, pH, TDS (Total Dissolved Solids), ammonia $\left(\mathrm{NH}_{3}\right)$, dan nitrat $\left(\mathrm{NO}_{3}{ }^{-}\right)$. Pengolahan data geolistrik menggunakan konfigurasi Wenner-Schlumberger. Selanjutnya untuk menganalisis data potensi cadangan airtanah digunakan Persamaan Darcy. Parameter kualitas airtanah dianalisis menggunakan matching data, yaitu mencocokkan data penelitian dengan baku mutu persyaratan air minum menurut Peraturan Menteri Kesehatan Nomor 492 Tahun 2010. Hasil penelitian menunjukkan bahwa perubahan penggunaan lahan mempengaruhi potensi cadangan dan kualitas airtanah di Desa Dukuhwaluh., Kecamatan Kembaran, Kabupaten Banyumas. Potensi cadangan airtanah di Desa Dukuhwaluh hanya sebesar 2,39 liter/detik, termasuk dalam kriteria "sedang". Kualitas airtanah di sebagian wilayah Desa Dukuhwaluh sudah melebihi batas ambang baku mutu persyaratan air minum menurut Peraturan Menteri Kesehatan Nomor 492 Tahun 2010. Parameter kualitas airtanah yang melebihi baku mutu persyaratan air minum adalah kandungan amonia $(18,7 \mathrm{mg} / \mathrm{l})$ dan bakteri Escerichia colli (positif).
\end{abstract}

Kata-kata kunci: Kualitas Airtanah, Potensi Airtanah, Geolistrik, Persamaan Darcy, Desa Dukuhwaluh.

\begin{abstract}
Dukuhwaluh village has experienced rapid development over the last decade. Regional development causes changes in land use from non-built land to built land. This study was aimed to analyze effect of land use changes on potential reserves and quality of groundwater in Dukuhwaluh Village, Kembaran District, Banyumas Regency. This study
\end{abstract}


used survey method. The sampling technique used purposive area sampling. The research sample consisted of 4 sample points, consist of 2 sample points in the Dusun Dampit area and 2 sample points in Dusun Dukuhwaluh. The research data consisted of land use data, potential groundwater reserves, and groundwater quality parameters. Land use data were obtained from Dukuhwaluh Village Monograph data for 2010-2020. Data of groundwater potential reserves was carried out using geoelectric, while groundwater quality data were measured directly in situ and laboratory tests. The water quality parameters measured included content of Escherichia colli, pH, TDS (Total Dissolved Solids), ammonia (NH3), and nitrate (NO3-). Geoelectric data processing using the Wenner-Schlumberger configuration. Furthermore, to analyze the potential data for groundwater reserves, used the Darcy Equation. Groundwater quality parameters were analyzed using data matching, namely matching research data with quality standards for drinking water requirements according to the Regulation of the Minister of Health Number 492 of 2010. The results showed that changes in land use affect the potential of reserves and groundwater quality in Dukuhwaluh Village, Kembaran District, Banyumas Regency. The potential for groundwater reserves in Dukuhwaluh Village was only 2.39 liters/second, was included in the "medium" criteria. The quality of groundwater in some areas of Dukuhwaluh Village has exceeded the quality standard threshold for drinking water requirements according to the Regulation of the Minister of Health Number 492 of 2010. The groundwater quality parameters that exceed of quality standards for drinking water requirements were content of ammonia (18.7 $\mathrm{mg} / \mathrm{l}$ ) and Escerichia colli bacteria (positive).

\section{Keywords: quality of groundwater, potential reserves of groundwater, Darcy equation,} Dukuhwaluh village.

\section{PENDAHULUAN}

Desa Dukuhwaluh merupakan salah satu desa di Kecamatan Kembaran, Kabupaten Banyumas. Luas wilayah Desa Dukuhwaluh sebesar 214,6 ha, yang terdiri dari 3 dusun, yaitu Dusun Dukuhwaluh, Dusun Dukuhwulung dan Dusun Dampit. Desa Dukuhwaluh selama dekade terakhir ini mengalami perkembangan yang pesat sejak desa tersebut ditetapkan oleh Bupati Banyumas sebagai bagian dari wilayah perkotaan. Perkembangan wilayah yang pesat di Desa Dukuhwaluh ditandai dengan berubahnya penggunaan lahan yang semula banyak terdapat lahan pekarangan dan pertanian, berubah penggunannya menjadi lahan untuk pemukiman, perkantoran, dan kos-kosan. Perubahan penggunaan lahan ini tentunya mempengaruhi kondisi hidrologi di wilayah tersebut. Proses infiltrasi air hujan menjadi berkurang, namun justru laju aliran permukaan (run off) meningkat sehingga dapat mempengaruhi potensi cadangan air tanah. Selain itu, perubahan penggunaan lahan pekarangan menjadi pemukiman juga akan berpengaruh terhadap kualitas air tanahnya.

Menurut Butler and Davies (2011), perubahan penggunaan lahan dari lahan nonterbangun menjadi lahan terbangun menyebabkan terjadinya peningkatan aliran permukaan dan semakin sedikitnya cadangan airtanah. Hal ini terjadi karena jumlah air hujan yang meresap ke dalam tanah semakin sedikit dan sebagian besar menjadi aliran permukaan. Lebih lanjut Shalihati et al. (2017) menjelaskan bahwa perkembangan wilayah perkotaan menyebabkan banyaknya perubahan penggunaan lahan dari lahan non-terbangun menjadi lahan terbangun. Kondisi ini dapat menyebabkan terjadinya gangguan kondisi hidrologi di wilayah tersebut. 
Berbagai penelitian relevan telah dilakukan oleh beberapa peneliti di Indonesia. Cahyadi, et al. (2012) melakukan analisis pengaruh perubahan penggunaan lahan terhadap retensi potensial air oleh tanah pada kejadian hujan sesaat (studi kasus perubahan penggunaan lahan di DAS Garang Jawa Tengah). Prasetya, et al. (2016) melakukan penelitian tentang prediksi cadangan air tanah di Daerah Aliran Sungai (DAS) Cisadane. Lebih lanjut Surahman (2017) juga telah melakukan penelitian mengenai perubahan penggunaan lahan dan dampaknya terhadap karakteristik hidrologi Sub DAS Tanralili Provinsi Sulawesi Selatan menggunakan Model SWAT. Selanjutnya Setyowati (2018) juga telah melakukan studi literatur pengaruh penggunaan lahan terhadap kualitas air. Tujuan penelitian ini adalah untuk menganalisis pengaruh perubahan penggunaan lahan terhadap potensi cadangan airtanah dan kualitas air tanah di Desa Dukuhwaluh, Kecamatan Kembaran, Kabupaten Banyumas.

\section{METODE PENELITIAN}

Penelitian ini dilakukan pada Bulan November 2020 sampai Juli 2021. Lokasi penelitian di Desa Dukuhwaluh, Kecamatan Kembaran, Kabupaten Banyumas yang termasuk wilayah Daerah Aliran Sungai Pelus. Penelitian ini menggunakan metode survei, untuk memperoleh data perubahan penggunaan lahan, potensi cadangan airtanah, dan kualitas airtanah. Teknik pengambilan sampel menggunakan purposive area sampling. Sampel penelitian berjumlah 4 titik sampel, terdiri dari 2 titik sampel di wilayah Dusun Dampit dan 2 titik sampel Dusun Dukuhwaluh. Data penelitian terdiri dari data penggunaan lahan, potensi cadangan airtanah, dan parameter kualitas airtanah. Data penggunaan lahan diperoleh dari data Monografi Desa Dukuhwaluh dan Data Statistik tahun 2010-2020. Pengumpulan data potensi airtanah menggunakan geolistrik, sedangkan data kualitas airtanah dilakukan pengukuran langsung di lapangan dan uji laboratorium. Parameter kualitas air yang diukur meliputi kandungan bakteri Escherichia colli, pH, TDS (Total Dissolved Solids), ammonia $\left(\mathrm{NH}_{3}\right)$, dan nitrat $\left(\mathrm{NO}_{3}{ }^{-}\right)$. Pengolahan data geolistrik menggunakan konfigurasi Wenner-Schlumberger. Selanjutnya untuk menganalisis data potensi cadangan airtanah digunakan Persamaan Darcy (Todd and Mays, 2005) (persamaan $1)$.

$$
Q=K \times A \times i
$$

dimana $\mathrm{K}=$ Konduktivitas Hidrolik, m/hari $(15,1002 \mathrm{~m} / \mathrm{hari}) ; \quad A=$ Luas Penampang Akuifer, $\mathrm{m}^{2}(W x$ bakuifer $)$; dan $\mathrm{i}=$ Gradien Hidrolik $\left(i=\frac{\delta h}{\delta L}\right)$.

Parameter kualitas airtanah dianalisis menggunakan matching data, yaitu mencocokkan data penelitian dengan baku mutu persyaratan kualitas air minum menurut Peraturan Menteri Kesehatan Nomor 492 Tahun 2010.

\section{HASIL DAN PEMBAHASAN}

\section{Perubahan Penggunaan Lahan Desa Dukuhwaluh Tahun 2010 - 2020}

Selama jangka waktu tahun 2010-2020, di wilayah Desa Dukuhwaluh telah terjadi perubahan penggunaan lahan pada beberapa dusun. Di Dusun Dukuhwaluh 1 terdapat alih fungsi lahan yang semula lahan persawahan menjadi lahan terbangun. Namun di Dusun Dukuhwaluh 1 masih terdapat lahan yang dimanfaatkan untuk persawahan yang lokasinya sangat dekat dengan permukiman penduduk. Sedangkan penggunaan lahan di Dusun Dukuhwaluh 2 sebagian besar dimanfaatkan untuk lahan permukiman padat. Penggunaan lahan di Dusun Dampit dimanfaatkan untuk lahan kebun, persawahan dan permukiman. Penggunaan lahan di Dusun Dampit termasuk tidak padat permukiman karena masih terdapat lahan yang dimanfaatkan untuk perkebunan dan persawahan. Secara keseluruhan, 
di Desa Dukuhwaluh selama kurun waktu 10 tahun (2010-2020) telah terjadi perubahan lahan yang signifikan. Data perubahan lahan di Desa Dukuhwaluh selama tahun 2010-2020 disajikan pada Tabel 1.

Tabel 1. Perubahan Penggunaan Lahan Desa Dukuhwaluh Tahun 2010-2020

\begin{tabular}{clcccc}
\hline \multirow{2}{*}{ No } & \multirow{2}{*}{ Penggunaan Lahan } & \multicolumn{2}{c}{ Tahun } & \multicolumn{2}{c}{ Keterangan Perubahan } \\
\cline { 3 - 6 } & & $\mathbf{2 0 1 0}$ & $\mathbf{2 0 2 0}$ & Ha & \% \\
\hline 1 & Badan Air & 1,724 & 1,724 & 0,000 & 0,00 \\
2 & Kebun Campuran & 5,248 & 1,264 & $(-) 3,985$ & 15,27 \\
3 & Permukiman & 74,693 & 87,210 & $(+) 12,518$ & 47,97 \\
4 & Lahan Terbuka & 1,039 & 1,567 & $(+) 0,529$ & 2,03 \\
5 & Sawah Irigasi & 100,597 & 91,535 & $(-) 9,062$ & 34,73 \\
& $\quad$ Jumlah & 183,300 & 183,300 & & 100 \\
\hline
\end{tabular}

Berdasarkan Tabel 1 diketahui bahwa di Desa Dukuhwaluh telah terjadi alih fungsi lahan pada lahan kebun campuran yang berkurang sebanyak 3,985 Ha (15,270\%). Alih fungsi lahan juga terjadi pada lahan sawah irigasi yang berkurang sebanyak 9,062 $\mathrm{Ha}$ $(34,730 \%)$. Hal tersebut disebabkan karena bertambahnya lahan yang dijadikan sebagai lahan permukiman yaitu sebanyak 12,518 $\mathrm{Ha}(47,973 \%)$. Lahan terbuka juga bertambah sebanyak $0,529 \mathrm{Ha}(2,026 \%)$. Secara keseluruhan, perubahan penggunaan lahan di Desa Dukuhwaluh tahun 2010-2020 sebesar 26,094 ha (14,235\%). Alih fungsi lahan yang paling mendominasi terjadi pada lahan permukiman yang semakin bertambah. Sedangkan lahan yang berkurang terdiri dari lahan kebun campuran dan lahan sawah irigasi.

\section{Potensi Airtanah}

Data potensi airtanah diperoleh secara langsung dari pengukuran ketebalan akuifer tanah menggunakan geolistrik. Pengambilan sampel potensi airtanah dilakukan di wilayah Dusun Dampit dan Dusun Dukuhwaluh. Wilayah Dusun Dampit mewakili wilayah yang didominasi lahan persawahan dan pekarangan, sedangkan wilayah Dusun Dukuhwaluh mewakili wilayah yang didominasi lahan pemukiman padat. Data yang diperoleh dari lapangan berupa data kuat arus listrik (V) dan data beda potensial (I) pada setiap lintasan. Besarnya nilai resistivitas dikelompokkan berdasarkan kedalaman tiap lapisan. Data hasil penelitan kemudian diolah menggunakan Microsoft Excel, Notepad dan Res2Dinv 2D. Data yang telah tersusun sesuai dengan format teks dokumen (.txt) kemudian diolah menggunakan aplikasi Res2Dinv $2 D$ sehingga didapatkan penampang melintang. Setelah tahapan-tahapan tersebut selesai dan didapatkan gambar penampang melintang pada masing-masing lintasan, selanjutnya diinterpretasikan berdasarkan nilai resistivitas sebenarnya dengan memperhatikan nilai tahanan jenis menurut Telford, et al. (1990) dan keadaan geologi di daerah penelitian sehingga dapat diketahui daerah yang diindikasikan sebagai sebaran akuifer.

Distribusi nilai tahanan jenis bawah permukaan dapat diketahui berdasarkan citra warna. Pengolahan data hasil penelitian metode geolistrik dilakukan menggunakan aplikasi Res2Dinv 2D dengan konfigurasi Wenner-Schlumberger, sehingga diperoleh model inversi suatu penampang bawah permukaan berupa citra warna seperti yang terlihat pada Gambar 1 dan Gambar 2.

a. Lintasan Pertama

Lintasan pertama berlokasi di Dusun Dukuhwaluh yang merupakan jalan setapak pada areal pemukiman padat. Lintasan pertama sepanjang 195 meter berada pada koordinat 741'29.99" "'" LS - 109²6'80.61"52" BT dan 741'12.26"38" LS - 109²6'78.04"36"” 
BT dengan elevasi sekitar 96 mdpl. Jarak atau spasi antar elektroda sepanjang 15 meter dengan arah penampang membujur dari arah utara ke selatan. Berdasarkan hasil pengukuran diperoleh nilai resistivitas berkisar antara 8,31-700 $\Omega \mathrm{m}$ dengan iterasi sebanyak 4 Abs dan RMS eror sebesar 10,5\%. Gambar 1 merupakan model inversi lintasan pertama hasil pengolahan data menggunakan Res2Dinv $2 D$.
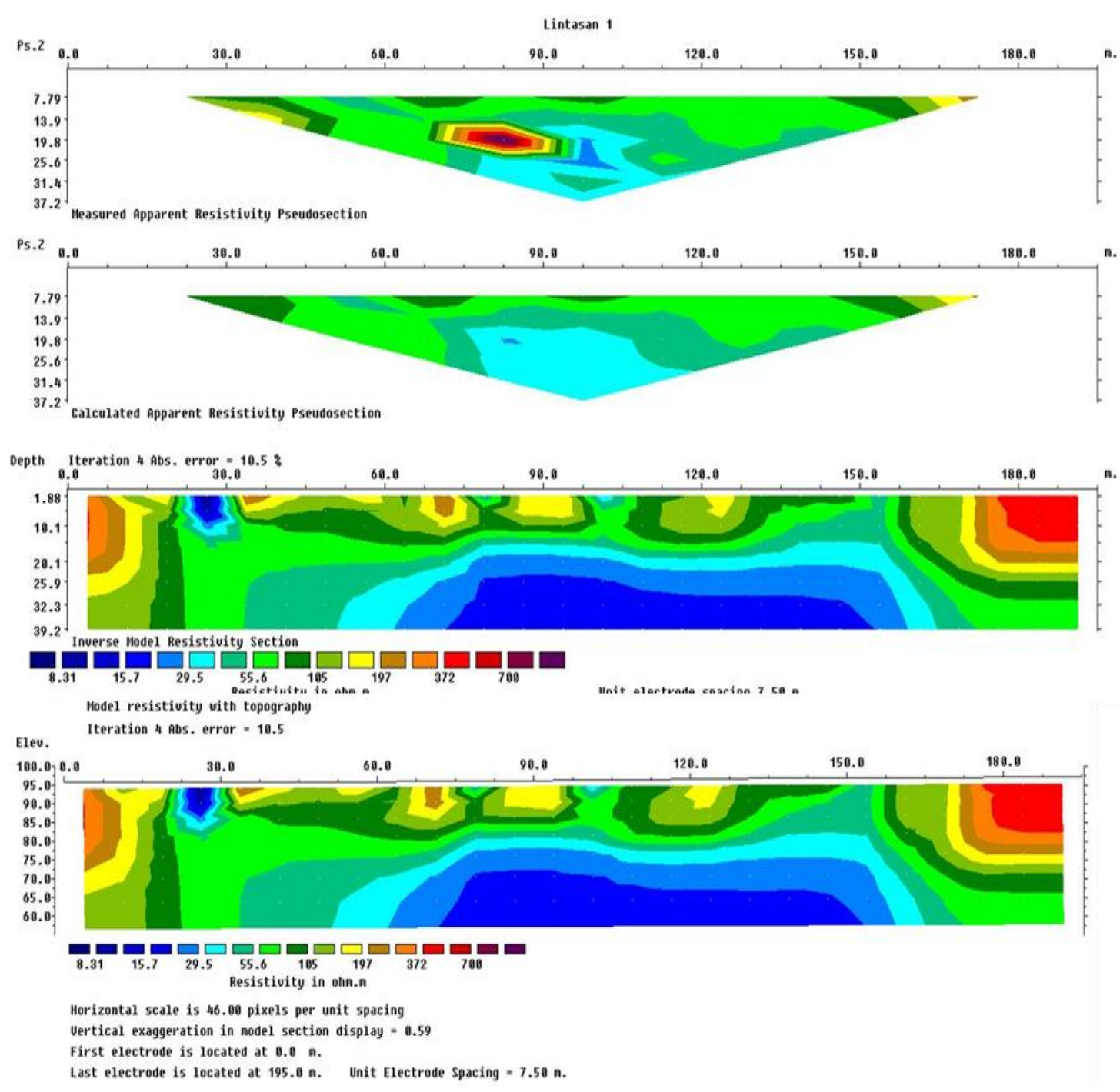

Gambar 1. Pempang resistivitas hasil inversi Res2Dinv 2D Lintasan Pertama (a) kontur resistivitas semu pengukuran (b) kontur resistivitas semu hasil perhitungan (c) kontur resistivitas sebenarnya dari pemodelan inversi (Telford et al.,1990) (d) kontur resistivitas sebenarnya dengan pemodelan inversi menggunakan topografi.

Lapisan berwarna biru tua hingga biru muda diinterpretasikan sebagai lapisan airtanah dengan rentang nilai tahanan jenis, yaitu $8,31-29,5 \Omega \mathrm{m}$. Kedalaman sumur di sekitar lintasan pertama antara 3 - 7 meter. Nilai tahanan jenis dan material lintasan pertama disajikan pada Tabel 2. 
Tabel 2. Nilai tahanan jenis dan material lintasan pertama

\begin{tabular}{ccc}
\hline No. & Nilai tahanan jenis $(\mathbf{\Omega m})$ & Material \\
\hline 1. & $8,31-29,5$ & Lempung \\
2. & $29,5-197$ & Pasir Sedang \\
3. & $397-700$ & Batu Pasir Pori-Pori Sedang \\
\hline
\end{tabular}

\section{b. Lintasan Kedua}

Lintasan kedua berlokasi di Dusun Dampit, merupakan areal persawahan sepanjang 195 meter. Lintasan kedua berada pada koordinat 740'70.18"55'" LS - 109 $26^{\prime} 79.93$ "79"” BT dan 740'75.33"56"' LS - 109 26'61.36”03"' BT dengan elevasi sekitar 100 mdpl. Jarak atau spasi antar elektroda sepanjang 15 meter dengan arah penampang membujur dari arah utara ke selatan. Berdasarkan hasil pengukuran diperoleh nilai resistivitasnya berkisar antara 8,62-371 $\Omega \mathrm{m}$ dengan iterasi sebanyak 4 Abs dan RMS eror sebesar 27,2\%. Gambar 2 merupakan model inversi pada lintasan kedua hasil pengolahan data dengan Res2Dinv $2 D$.
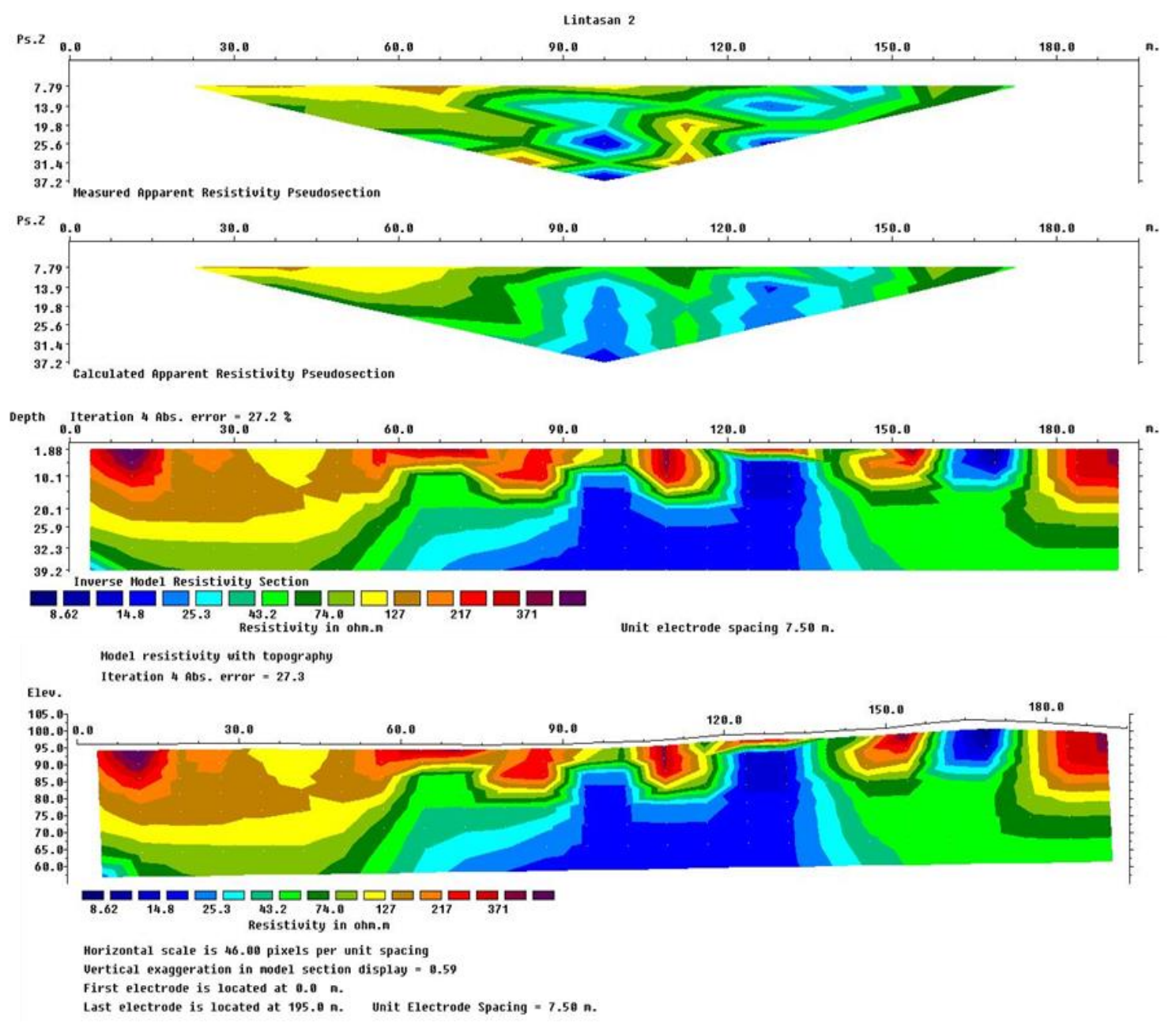

Gambar 2. Pempang resistivitas hasil inversi Res2Dinv 2D Lintasan Kedua (a) kontur resistivitas semu pengukuran (b) kontur resistivitas semu hasil perhitungan (c) kontur resistivitas sebenarnya dari pemodelan inversi (Telford et al.,1990) (d) kontur resistivitas sebenarnya dengan pemodelan inversi menggunakan topografi. 
Lapisan berwarna biru tua hingga biru muda diinterpretasikan sebagai lapisan airtanah dengan rentang nilai tahanan jenis antara 8,62 - 25,3 $\Omega \mathrm{m}$. Kedalaman sumur di sekitar lintasan kedua antara 3 - 10 meter. Nilai tahanan jenis dan material lintasan 2 disajikan pada Tabel 3 .

Tabel 3. Nilai tahanan jenis dan material lintasan kedua

\begin{tabular}{rcc}
\hline No. & Nilai tahanan jenis $(\mathbf{\Omega m})$ & Material \\
\hline 1. & $8,62-25,3$ & Lempung \\
2. & $25,3-127$ & Pasir Sedang \\
3. & $127-371$ & Batu Pasir Pori-Pori Sedang \\
\hline
\end{tabular}

Nilai potensi airtanah pada lokasi penelitian dapat diketahui dengan menggunakan persamaan Darcy. Parameter yang digunakan untuk mengisi persamaan tersebut adalah konduktivitas hidraulik, gradien hidraulik dan luas penampang akuifer. Luas penampang akuifer (A) diperoleh dengan mengalikan panjang penampang akuifer (W) dengan ketebalan akuifer ( $b_{\text {akuifer }}$ ). Gradien hidraulik diperoleh dengan membagi beda ketinggian muka airtanah $(\delta \mathrm{h})$ dengan panjang lintasan airtanah $(\delta \mathrm{L})$. Debit airtanah dihitung dari perkalian antara konduktivitas hidraulik (K), luas penampang akuifer (A) dan gradien hidraulik (i). Konduktivitas hidrolik di Desa Dukuhwaluh pada lintasan pertama dan lintasan kedua memiliki material yang sama yaitu material pasir sedang, batu pasir poripori sedang, dan lempung dengan nilai konduktivitas hidrolik berturut-turut sebesar 12 $\mathrm{m} /$ hari; $3,1 \mathrm{~m} /$ hari; dan $0.0002 \mathrm{~m} /$ hari.

Hasil perhitungan debit airtanah pada lintasan 1 sebesar 2,12 liter/detik, sedangkan pada lintasan 2 sebesar 2,66 liter/detik. Rata-rata debit airtanah di Desa Dukuhwaluh sebesar 2,39 liter/detik. Klasifikasi debit airtanah menurut Keputusan Menteri ESDM No.1451 K/10/ MEM/2000, yaitu "besar" (>10 liter/detik,) "sedang" (2 - 10 liter/detik), dan "kecil" (< 2 liter/detik). Hasil perhitungan debit airtanah di Desa Dukuhwaluh secara lengkap disajikan pada Tabel 4.

Tabel 4. Kriteria debit airtanah Desa Dukuhwaluh

\begin{tabular}{cccc}
\hline No. & Lokasi & Debit Airtanah & Kriteria \\
\hline 1 & Lintasan 1 & 2,12 liter/detik & Sedang \\
2 & Lintasan 2 & 2,66 liter/detik & Sedang \\
& Rata-rata & 2,39 liter/detik & Sedang \\
\hline
\end{tabular}

Hasil pengukuran debit air di lintasan 2 lebih besar dibandingkan lintasan 2. Hal ini disebabkan karena lintasan 1 berada di area pemukiman padat, sedangkan lintasan 2 berada di lokasi persawahan. Kebutuhan airtanah di lokasi pemukiman lebih tinggi dibandingkan di lokasi persawahan sehingga potensi airtanah di lokasi pemukiman lebih rendah karena adanya pemanfaatan airtanah yang tinggi. Namun secara keseluruhan, potensi cadangan airtanah di Desa Dukuhwaluh termasuk dalam kriteria "sedang". Hasil penelitin ini selaras dengan hasil penelitian Suwarsito et al., (2021) yang menyatakan bahwa potensi cadangan airtanah di kampus Universitas Muhammadiyah Dukuhwaluh sebesar 4,07 liter/detik, termasuk dalam kriteria "sedang". Hal ini menunjukkan bahwa di Desa Dukuhwaluh telah terjadi penurunan potensi airtanah di beberapa lokasi. Berdasarkan hasil penelitian, di Desa Dukuhwaluh telah terjadi perubahan penggunaan lahan sebesar 26,094 ha (14,235\%). Perubahan penggunaan lahan terjadi pada lahan kebun campuran dan sawah menjadi lahan pemukiman. Hal ini dapat menyebabkan terjadinya penurunan laju infiltrasi air hujan ke dalam tanah, sehingga aliran permukaan semakin besar saat terjadi hujan. Selain itu, pemanfaatan airtanah oleh warga pemukiman juga berpengaruh terhadap ketersediaan 
airtanah. Semakin bertambah warga pemukiman, semakin besar airtanah yang diambil untuk menopang kebutuhan hidup akan airtanah.

Di samping faktor perubahan penggunaan lahan, faktor lain yang mempengaruhi potensi cadangan airtanah di Desa Dukuhwaluh adalah curah hujan, vegetasi, dan jenis akuifer. Berdasarkan sumber data dari Dinas Pengelolaan Sumber Daya Air Serayu Citanduy Kabupaten Banyumas tahun 2019, curah hujan yang terjadi di Desa Dukuhwaluh termasuk tinggi dengan rata-rata 3.180,75 mm/tahun. Curah hujan yang tinggi tersebut berpotensi meningkatkan cadangan air tanah di Desa Dukuhwaluh melalui proses infiltrasi ke dalam tanah. Vegetasi pepohonan dan rumput yang terdapat di Desa Dukuhwaluh juga berpengaruh terhadap potensi cadangan airtanah. Jenis vegetasi yang terdapat di Desa Dukuhwaluh berupa tanaman keras dan rumput-rumputan. Jenis tanaman keras misalnya pohon kelapa, jati, mahoni, ketapang, abasia, sengon, dan lain-lain. Namun jumlah vegetasi di Desa Dukuhwaluh mulai berkurang seiring dengan bertambahnya bangunan fisik untuk pemukiman, perkantoran, rumah sakit dan sebagainya di desa tersebut sehingga dapat menurunkan potensi cadangan airtanah. menurut pernyataan Abdulgani (2015), pembangunan fisik pada suatu lahan dapat menyebabkan berkurangnya area resapan yang mengakibatkan terjadinya penurunan laju infiltrasi dan bertambahnya laju aliran permukaan (run off).

\section{Kualitas Airtanah Desa Dukuhwaluh}

Pengukuran kualitas airtanah dilakukan secara langsung di lapangan dan uji laboratorium. Parameter kualitas airtanah yang diukur meliputi kandungan bakteri Escherichia colli, pH, TDS (Total Dissolved Solids), ammonia $\left(\mathrm{NH}_{3}\right)$, dan nitrat $\left(\mathrm{NO}_{3}{ }^{-}\right)$. Sampel airtanah diambil dari 4 titik pengambilan sampel, yaitu 2 titik sampel di wilayah Dusun Dampit dan 2 titik sampel di Dusun Dukuhwaluh. Sampel I dan II diambil dari lokasi di Dusun Dukuhwaluh, masing-masing titik sampel mewakili lahan pemukiman dan pekarangan. Sampel III dan IV diambil dari lokasi di Dusun Dampit, masing-masing titik sampel mewakili lahan pemukiman dan persawahan. Hasil pengukuran parameter kualitas airtanah disajikan pada Tabel 5.

Tabel 5. Hasil Pengukuran Parameter Kualitas Airtanah

\begin{tabular}{|c|c|c|c|c|c|c|}
\hline \multirow[b]{2}{*}{ No } & \multirow[b]{2}{*}{ Lokasi Pengambilan Sampel } & \multicolumn{5}{|c|}{ Parameter } \\
\hline & & E. choli & $\mathbf{p H}$ & $\begin{array}{c}\text { TDS } \\
(\mathrm{mg} / \mathrm{l})\end{array}$ & $\begin{array}{c}\mathrm{NH}_{3} \\
(\mathrm{mg} / \mathrm{l})\end{array}$ & $\begin{array}{c}\mathrm{NO}_{3}{ }^{-} \\
(\mathrm{mg} / \mathrm{l})\end{array}$ \\
\hline 1 & Sampel I (Dusun Dukuhwaluh) & Positif & 7,6 & 168 & 0,10 & 13,9 \\
\hline 2 & Sampel II (Dusun Dukuhwaluh) & Negatif & 7,5 & 170 & 18,7 & 18,5 \\
\hline 3 & Sampel III (Dusun Dampit) & Positif & 7,2 & 169 & 0,10 & 12,8 \\
\hline 4 & Sampel IV (Dusun Dampit) & Negatif & 7,3 & 165 & 0,08 & 9,5 \\
\hline
\end{tabular}

Berdasarkan data pada Tabel 5, kandungan bakteri E. choli dijumpai pada sampel I dan sampel III. Hal ini menunjukkan bahwa pada sampel I dan III sudah tercemar dengan bakteri E. choli. Menurut Peraturan Menteri Kesehatan Nomor 492 Tahun 2010, air yang terdeteksi mengandung bakteri E. colli sudah tidak layak digunakan untuk keperluan air minum. Sampel I dan sampel III merupakan sampel yang diambil dari area pemukimam penduduk yang relatif padat. Diduga bahwa pada area pemukimam yang relatif padat tersebut, keberadaan pembuangan limbah rumah tangga, terutama keberadaan septic tank tidak teratur dan saling berdekatan sumber airtanah. Kondisi sumber air yang dekat dengan sumber cemaran akan menyebabkan sumber air mudah tercemar, misalnya pada sumur yang letaknya dekat dengan septic tank. Air yang berasal dari septic tank dapat meresap ke 
sumber airtanah sehingga dapat terkontaminasi dengan bakteri (Ningrum, 2018). Adanya bakteri coliform di dalam air mengindikasikan bahwa air tersebut sudah tercemar oleh tinja manusia maupun kotoran hewan (Pelczar and Chan, 2008).

Data pada Tabel 5 terlihat bahwa hasil pengukuran $\mathrm{pH}$ dan TDS airtanah pada semua titik sampel tidak melebihi nilai ambang baku mutu persyaratan air minum yang ditetapkan oleh Peraturan Menteri Kesehatan Nomor 492Tahun 2010. Menurut Peraturan Menteri Kesehatan tersebut, batas ambang nilai $\mathrm{pH}$ dan TDS untuk persyaratan air minum adalah 6,5 - 8,5 dan $500 \mathrm{mg} / \mathrm{l}$. Dengan demikian, ditinjau dari nilai $\mathrm{pH}$ dan TDS airtanah di Desa Dukuhwaluh masih layak digunakan untuk keperluan air minum.

Hasil pengukuran kandungan ammonia airtanah pada Tabel 5 terlihat bahwa kandungan ammonia pada sampel I, III, dan IV masih rendah, namun pada sampel II kandungan ammonianya sangat tinggi. Menurut Peraturan Menteri Kesehatan Nomor 492 Tahun 2010, persyaratan kandungan ammonia yang layak untuk air minum maksimal 1,5 $\mathrm{mg} / \mathrm{l}$. Dengan demikian, ditinjau dari kandungan ammonianya, sampel I, II, dan IV masih layak untuk keperluan air minum, sedangkan sampel II sudah tidak layak untuk keperluan air minum karena melebihi batas ambang persyaratan air minum menurut Peraturan Menteri Kesehatan tersebut. Sampel II diambil dari area pekarangan yang terletak di pinggiran pemukiman. Area pekarangan tersebut dulunya merupakan area persawahan rawa-rawa yang terletak di dataran rendah yang sering tergenang air. Area pekarangan tersebut dulunya juga sering digunakan sebagai tempat pembuangan sampah penduduk sekitar. Namun area persawahan tersebut sekarang telah berubah menjadi pekarangan. Walaupun area tersebut telah berubah menjadi pekarangan, namun kualitas air tanahnya masih rendah terutama kandungan ammonianya. Hasil penelitin ini selaras dengan hasil penelitian yang dilakukan Suwarsito et al., (2020), bahwa kandungan ammonia airtanah di Desa Karangsari sebesar 6,626 mg/l sehingga melebihi batas ambang kelayakan untuk budidaya ikan lele.

Hasil pengujian kandungan nitrat airtanah pada Tabel 5 menunjukkan nilainya relatif tinggi pada semua sampel. Namun kandungan nirat tersebut tidak melebihi batas ambang baku mutu persyaratan kualitas air minum yang ditetapkan oleh Peraturan Menteri Kesehatan Nomor 492 Tahun 2010. Menurut Peraturan Menteri Kesehatan Nomor 492 Tahun 2010, persyaratan kandungan nitrat yang layak untuk air minum maksimal $50 \mathrm{mg} / \mathrm{l}$. Dengan demikian, ditinjau dari kandungan nitratnya, airtanah di Desa Dukuhwaluh masih layak untuk keperluan air minum.

\section{KESIMPULAN}

Hasil penelitian menunjukkan bahwa perubahan penggunaan lahan mempengaruhi potensi cadangan dan kualitas airtanah di Desa Dukuhwaluh., Kecamatan Kembaran, Kabupaten Banyumas. Potensi cadangan airtanah di Desa Dukuhwaluh hanya sebesar 2,39 liter/detik, termasuk dalam kriteria "sedang". Kualitas airtanah di sebagian wilayah Desa Dukuhwaluh sudah melebihi batas ambang baku mutu persyaratan air minum menurut Peraturan Menteri Kesehatan Nomor 492 Tahun 2010. Parameter kualitas airtanah yang melebihi baku mutu persyaratan air minum adalah kandungan amonia $(18,7 \mathrm{mg} / \mathrm{l})$ dan bakteri Escerichia colli (positif). Berdasarkan hasil penelitian ini disarankan kepada pihak Pemerintah Desa Dukuhwaluh untuk membatasi pengalihfungsian lahan kebun campuran dan sawah menjadi pemukimam agar ketersediaan lahan terbuka hijau tidak semakin berkurang sehingga kualitas airtanah dan cadangan airtanah meningkat. 


\section{UCAPAN TERIMA KASIH}

Penulis mengucapkan terima kasih kepada Lembaga Penelitian dan Pengabdian pada Masyarakat Universitas Muhammadiyah Purwokerto yang telah memberikan dana penelitian ini.

\section{DAFTAR PUSTAKA}

Abdulgani. H. (2015). Efektifitas Model Sistem Resapan Horizontal dengan Parit Infiltrasi dalam Mengurangi Limpasan Permukaan. Jurnal Rekayasa Infrastruktur, Volume 1 Nomor 1: $36-43$.

Butler, D. dan Davies, J. W. (2011). Urban Drainage.Third Edition. New York: Taylor and Francis Group.

Cahyadi, A., A. Yananto, M.S. Wijaya, dan H. Nugraha. (2012). Analisis Pengaruh Perubahan Penggunaan Lahan Terhadap Retensi Potensial Air oleh Tanah Pada Kejadian Hujan Sesaat (Studi Kasus Perubahan Penggunaan Lahan di DAS Garang Jawa Tengah). Prosiding Seminar Nasional Informatika 2012 UPN "Veteran" Yogyakarta, 30 Juni 2012; hal E1 -7.

Ningrum, S.O. (2018). Analisis Kualitas Badan Air dan Kualitas Air Sumur di Sekitar Pabrik Gula Rejo Agung Baru Madiun. Jurnal Kesehatan Lingkungan, Volume 10 Nomor 1: $1-12$.

Pelczar, M.J. dan E.C.S. Chan. (2008). Dasar-Dasar Mikrobiologi. Penerbit Universitas Indonesia Press.

Prasetya, D.A., R.S.B. Waspodo, and S.K. Saptomo. (2016). Prediksi Cadangan Air Tanah di Daerah Aliran Sungai (DAS) Cisadane. Jurnal Teknik Sipil dan Lingkungan, Volume 1 Nomor 2: 59 - 68

Shalihati, S.F., Sutomo, dan Suwarno. (2017). Analisis Dominasi Penggunaan Lahan Kekotaan dan Kedesaan di Kecamatan Kembaran. JSSH, Volume I Nomor 2: 147 162.

Setyowati, R.D.N. (2018). Studi Literatur Pengaruh Penggunaan Lahan Terhadap Kualitas Air. Jurnal Ilmu-Ilmu Teknik - Sistem, Volume 12 Nomor 1: 7 - 15.

Surahman, S. (2017). Perubahan Penggunaan Lahan dan Dampaknya terhadap Karakteristik Hidrologi Sub DAS Tanralili Provinsi Sulawesi Selatan Menggunakan Model SWAT. Jurnal Agrotan Volume 3 Nomor 2: 50-67.

Suwarsito, A.H.Z. Kamila, dan C. Purbomartono. (2020). Kajian Kesesuaian Kualitas Airtanah untuk Budidaya Ikan Lele (Clarias gariepinus) di Desa Karangsari, Kecamatan Kembaran, Kabupaten Banyumas. Sainteks Volume 17 Nomor 1: 1 - 6.

Suwarsito, A.R. Dirgantara, dan E. Sarjanti. (2021). Kajian Potensi Cadangan Airtanah di Area Kampus Universitas Muhammadiyah Purwokerto Menggunakan Metode Geolistrik. Jurnal Riset Sains dan Teknologi (JRST) Volume 5 Nomor 1: 1 - 8.

Telford, W.M., L.P. Geldart, R.E. Sheriff, and D.A. Keys. (1990). Applied Geophysics. Cambridge University Press - Science.

Todd, D.K. and L.W. Mays. (2005). Groundwater Hydrology. 3rd edition. John Wiley \& Sons, New York. 